\title{
MODELLING SPOT PRICES IN DEREGULATED WHOLESALE ELECTRICITY MARKETS: A SELECTED EMPIRICAL REVIEW
}

\author{
HELEN HigGS \& ANDREW C. WORTHINGTON
}

\begin{abstract}
The restructuring and deregulation of global electricity markets has brought about fundamental changes in the behaviour of wholesale spot prices. In turn, this has fostered a small but increasing volume of literature aimed at modeling and providing best-practice forecasts of electricity prices and price volatility, often employing very high-frequency data. The purpose of this paper is to review the various time-series regression modeling approaches as they apply to competitive electricity markets throughout the world. Apart from discussing the strengths and weaknesses of the different approaches and their key findings, the paper also examines the steps faced by researchers as they move through the modeling process. Accordingly, the article provides guidance to those conducting empirical research on electricity prices and serves as an aid for policymakers, managers and practitioners interpreting electricity pricing research outcomes.
\end{abstract}

Subject category:

Econometric modelling

Keywords:

Wholesale electricity prices, high-frequency data, electricity price and price volatility forecasting

Helen Higgs and Andrew Worthington are in the Department of Accounting, Finance and Economics, Griffith University, 170 Kessels Road, Nathan QLD 4111, Australia.

Email correspondence: a.wortbington@griffith.edu.au 


\section{INTRODUCTION}

The restructuring and deregulation of global electricity markets has brought about fundamental changes in the behaviour of wholesale spot prices. In very many OECD markets - including Australia, Canada, the Netherlands, Germany, New Zealand, Scandinavia, Spain, the United Kingdom and the United States - a diverse mix of public and/or private market designs now mean that competitive forces are playing a much more important role in determining the price of electricity than they did previously. In sharp contrast to markets in the past, prices are now often characterized by high volatility (the variance of prices is very large), strong meanreversion (prices tend to fluctuate around a long-term equilibrium), and abrupt and unanticipated upward price jumps or spikes which quickly decay (associated with shocks to price-inelastic demand and supply). In turn, these can reflect the inherent characteristics of competitive electricity markets: seasonality, low marginal production costs, the impact of system breakdowns or outages, constraints on the interconnection between regions, limited storability, and even market manipulation. The market designs and rules set in place to help these competitive markets achieve their desired policy objectives, including consumer and environmental protection and resource sustainability, also have a role to play.

Clearly, knowledge of the dynamics of wholesale spot and related prices is of importance for successful business strategies relating to competition, real and financial asset valuation and risk management for electricity generators, retailers, end-users and good policy for governments. To start with, modeling prices accurately is important for generation assets. This is particularly true for peaking plants, whose value may be entirely dependent on the existence of price spikes that facilitate the recovery of high marginal costs and the recouping of fixed costs over very short running periods. Generators can also use the information on prices to gauge the potential competition from other suppliers or the potential opportunity of servicing customers in other regions. Large users are also concerned with the better modeling of prices because of cost efficiencies associated with load shedding during peak periods, while retailers can benefit from improved forecasting of volatility to hedge against upside price risk. We can also use realistic appraisals of the volatility of spot prices to determine the financial value of electricity derivatives. Finally, governments creating and modifying market rules benefit from knowledge of the outcomes of electricity systems and their compatibility with policy objectives.

While the modeling of competitive electricity markets is still in its infancy, since the early 1990s a small but increasing literature has considered electricity spot prices using advanced econometric models. The purpose of this paper is to review these various time-series regression-modeling approaches as they apply to competitive electricity markets throughout the world. Apart from discussing the strengths and weaknesses of the different approaches, the paper also examines the steps faced by researchers as they progressively move through the modeling process. This highlights the empirical problems that have received attention in the literature, and the efforts by researchers to overcome these problems. We also discuss the key findings of these studies. Accordingly, the paper provides guidance to those conducting empirical research on spot electricity prices and as an aid for policymakers, managers and practitioners interpreting the outcomes of extant and future studies. 


\section{The Nature of Electricity Prices and the Scope of the Survey}

Despite the key importance of market pricing within spot markets and the integration of many regional electricity markets within a single national or international market, very few empirical studies currently exist concerning the pricing behaviour of deregulated electricity markets. This is important, not only because "...the spot price strongly influences the contract price which, in turn, largely dictates the final price for consumer [but also] because the spot price represents a considerable element of cost for direct purchasers of power, such as large industrial companies" (Robinson, 2000: 527). The short life of these markets is the most apparent though not the only reason. In actual fact, very little work has been undertaken that provides a detailed understanding of electricity price behaviour and almost none using the advanced econometric techniques so increasingly widespread in work on, say, financial markets. The few studies that do exist are especially noteworthy and are presented below.

Electricity supply and demand are subject to economic and business activities and weather conditions. Demand for this essential good is highly inelastic. At times of low demand, electricity is supplied using the base-load units with low marginal costs. At times of high demand during summer and winter months or weekdays as compared to weekends, generators at higher marginal costs are scheduled into the pool. Knittel and Roberts (2001), Lucia and Schwartz (2002), Escribano et al. (2002), Guthrie and Videbeck (2002), Hadsell et al. (2004), Higgs and Worthington (2005) and Koopman (2007) have included seasonal factors in their studies.

Further increases in demand due to weather conditions push up prices, as more expensive generators enter the pool. This leads to some degree of mean-reversion in prices. A mean-reversion process has a drift term that brings the time series variable of interest back to the equilibrium level. The stronger the mean-reversion the quicker is the return of the variable from some extreme position away from equilibrium back to it. Studies profiling mean-reversion models include Deng (2000), Knittel and Roberts (2001) and Escribano et al. (2002). Some studies also show the interaction of the degree of mean-reversion with price spikes that can occur after unexpected outages of generators or transmission lines. Deng (2000), Huisman and Mahieu (2003) and Bierbrauer et al. (2004) incorporate jumps, regime switching and stochastic volatility in the mean-reversion models to capture the uncertainty in the load due to forecasting errors.

The move towards liberalization of the electricity supply industry has lowered electricity prices but has made pricing more volatile, with features of persistence and volatility clustering. The measures of volatility illustrate the degree of randomness or risk in the spot electricity prices and it is an important variable in the valuation of risk management models. Possible models - such as autoregressive moving average (ARMA), autoregressive conditional heteroscedasticity (ARCH) or generalized autoregressive conditional heteroscedasticity (GARCH) processes-allow volatility shocks to cluster and persist over time and to revert to some more normal level and so may offer potentially interesting insights on the volatility observed in the electricity markets. Robinson and Taylor (1998), Knittel and Roberts (2001), Escribano et al. (2002), Solibakke (2002) and Goto and Karolyi (2003) use ARMA and GARCH models to investigate the conditional mean and volatility characteristics of spot electricity markets while Solibakke (2002) and Hadsell et al. 
(2004) extend the ARCH process to the Exponential ARCH (EARCH) and threshold ARCH (TARCH) processes to take account of asymmetric response in the spot electricity prices. Higgs and Worthington (2005) employ more sophisticated ARCH techniques such as the normal Asymmetric Power ARCH (APARCH), Student (APARCH) and skewed Student (APARCH) to model the time-varying variance in spot electricity prices.

All of the abovementioned studies investigate the intra-relationship of each regional electricity market whereby univariate time-series techniques are used to encapsulate the dynamics of spot electricity prices. There are very few studies on the integration or inter-relationship of regional electricity markets (see, for instance, De Vany and Walls, 1999a). These two researchers use co-integration analysis between pairs of regional markets to assess market integration, while Bystrom (2003) applies the constant correlation bivariate GARCH model to the short-term hedging of electricity spot prices with electricity futures. Worthington et al. (2005) extend the bivariate GARCH analysis to the multivariate GARCH process to identify the price and price volatility relationship between five Australian regional electricity markets.

\section{The Modeling of Electricity Prices}

The remainder of the literature review is divided into two sections: namely, multivariate versus univariate models to depict the behaviour of the spot electricity prices characterized by several distinguishing features. The multivariate models are employed to capture the interrelationships between spot electricity markets and how the effects of its own and other markets can be used to forecast the price movement of its own market. Modeling multivariate time series models involving more than one market depends on whether the series are stationary or non-stationary. If the series are non-stationary and an interesting feature concerning the series is cointegration or whether the series move together in the long-term, then cointegration techniques are used. If the series are stationary, regression or GARCH models can be appropriately employed to model the series. The univariate time series models are used to profile the 'stylized facts' or components that explain the intra-relationship of the spot electricity price series itself. All studies in the univariate context are found to be stationary and a family of GARCH and mean-reversion and regime switching models is widely used to investigate the reliability of the underlying price process in forecasting the spot electricity prices.

As all data used to model spot electricity prices are time series data, it is important to determine initially whether the series is stationary or non-stationary. The result of this test determines the appropriate quantitative methods to assess the dynamics of the series. The study by De Vany and Walls (1999a) finds the electricity pool prices to be non-stationary and hence uses co-integration analysis, while all other studies employ stationary techniques that involve a family of $\mathrm{ARCH}$ or GARCH and stochastic processes relating to regression techniques. The stationary techniques encompass two components; the deterministic and stochastic parts. The deterministic part of the stationary quantitative analysis extracts the predetermined information from the spot price thus leaving the volatile components in the residuals. These are then used to capture the volatility or risk of the spot electricity prices. Within the broad scope of modeling spot electricity prices, there are three main quantitative techniques: co-integration, a family of GARCH models, and 
stochastic models. As detailed in Table 1, these include multivariate models (De Vany and Walls, 1999a, Bystrom, 2003 and Worthington et al., 2005), univariate in terms of a family of GARCH processes (Robinson and Taylor, 1998; Knittel and Roberts, 2001; Escribano et al, 2002; Solibakke, 2002; Goto and Karolyi, 2003, Hadsell et al., 2004, Higgs and Worthington, 2005, Chan and Gray, 2006 and Koopman et al., 2007) and stochastic models including jumps and mean-reversion and spikes (Deng, 2000; Robinson, 2000; Knittel and Roberts, 2001; Escribano et al., 2002, Huisman and Mahieu, 2003 and Mount et al. 2006). Even though most research in terms of modelling the dynamics of electricity markets are summarized in Table 1, the section that follows the table discusses some of the well-cited papers in each of the multivariate, univariate and stochastic techniques.

\subsection{Multivariate Models}

Early work by De Vany and Walls (1999a) makes an interesting starting point as this is the only study that examines the inter-relationship between two regional spot electricity markets by questioning whether the highly complex western electricity transmission grid in the US has led to a more integrated electricity industry. This grid interconnects the entire western US, from Canada to Mexico and east as far as Montana, Utah and New Mexico under a structure of decentralization and deregulation.

De Vany and Walls (1999a) take a multivariate approach to understanding electricity pricing behaviour between regional power markets in eleven regional markets by examining evidence of integration over the period December 1994 to April 1996. These eleven regional markets are California/Oregon, Four-Corners, Central Rockies, Inland Southwest, Mead, Mid-Columbia, Midway/Sylmar, Northern California, Northwest/Northern Rockies, Palo Verde and Southern California. Using daily spot prices collected from the day ahead over-the-counter market, De Vany and Walls (1999a) employ Augmented Dickey-Fuller (ADF) unit root tests to first detect the presence of nonstationarity in both peak and off-peak series for each market. The presence of unit root or nonstationarity is evident in all series with the exception of off-peak prices in the Northern California market. There is evidence of stationarity in the first differences of the price series.

De Vany and Walls (1999a) also apply co-integration analysis of order one to test for price convergence between each of 55 pairs of markets during peak and off-peak periods. The random walk analysis is used to test for the strength of market integration between two markets; that is, how strongly and perfectly two markets are integrated. Finally, the existence of unit roots in eigenvalues of vector autoregressive processes is used to examine pricing stability in wholesale electricity markets. The results indicate a high degree of market integration between markets that are not necessarily physically connected: with co-integration being found for peak prices in forty-eight of the fifty-five market pairs (87 percent); and all fifty-five market pairs for off-peak prices. De Vany and Walls (1999a) argue that the lack of co-integration in several markets was evidence of transfer constraints within some parts of the Western Electricity Grid, though on the whole the study findings are suggestive of an efficient and stable wholesale power market. This is a noteworthy study as it is the only empirical analysis that explores the inter-relationship of spot electricity prices among pairs of regional markets applying the Augmented Dickey-Fuller and 
co-integration techniques. These methodologies are appropriate as the spot price series are non-stationary.

Bystrom (2003) examines the short-term hedging performance of the Nordic spot electricity price with electricity futures using different ways of estimating the minimum variance hedge ratio. The hedge ratio allows the investor to determine how many futures contracts can be bought or sold for each spot contract in order to minimize the variance of the returns of the portfolio. The logarithm of the daily spot and futures price series from 2 January 1996 to 21 October 1999 are stationary at levels. Five different hedge ratios are estimated: the naïve one-to-one hedge ratio where one spot contract is off-set by one futures contract; the time invariant OLShedge ratio; the dynamic moving average hedge ratio (50 days back in time); the constant conditional bivariate GARCH model to capture the time varying variance; and the orthogonal GARCH using principal components to generate the number of orthogonal factors. Based on the out-of sample forecasts on their ability to reduce the portfolio variance, the first two simpler hedge models perform better than the more sophisticated models. This study examines the inter-relationship between the spot and futures electricity markets rather than the inter-relationship between two regional markets as explored by De Vany and Walls (1999a).

Worthington et al. (2005) make further contributions using the multivariate GARCH (MGARCH) process to examine the inter-relationships among the five regional electricity markets in the Australian National Electricity Market (NEM): namely, New South Wales, Queensland, South Australia, the Snowy Mountains Hydroelectric Scheme and Victoria. The data employed in the study are daily spot prices for electricity encompassing the period from the date of commencement of the NEM on 13 December 1998 to 30 June 2001. Unit root tests confirm that Australian electricity spot prices are stationary. The MGARCH model is then used to identify the source and magnitude of spillovers. The estimated coefficients from the conditional mean price equations indicate that despite the presence of a national market for electricity, the regional electricity spot markets are not integrated. In fact, only two of the five markets exhibit a significant own mean spillover. Worthington et al. (2005) suggest, for the most part, that Australian spot electricity prices could not be usefully forecasted using lagged price information from either each market itself or from other markets in the national market. However, own-volatility and cross-volatility spillovers are significant for nearly all markets, indicating the presence of strong $\mathrm{ARCH}$ and GARCH effects. Conventionally, this is used to indicate that markets are not efficient. Strong own and cross-persistent volatility are also evident in all Australian electricity markets. This indicates that while the limited nature of the interconnectors between the separate regional markets prevents full integration, shocks or innovations in particular markets still exert an influence on price volatility.

The main advantage of multivariate time series studies is that they can assess the price and volatility information flows of the interconnected markets. This allows for a better understanding of the spot electricity dynamics by electricity producers, transmitters and retailers and the efficient distribution of energy on a national level. On the other hand, the disadvantages are that they do not take into account of the full nature of the interdependence and mean-reversion of the price and volatility interrelationships between these separate markets. Spot prices are mean reverting as weather is a dominant factor influencing the equilibrium price, through changes in 
demand. The cyclical nature of weather conditions tends to pull price back to its mean level and this should be included in modeling the dynamics of the interrelationships between electricity markets.

\subsection{Univariate Models}

The remainder of this paper is based on stationary time series and univariate techniques to profile the intra-relationship of spot electricity markets. The main feature is an appraisal of research using a variety of stationarity tests, vector autoregressive (VAR), autoregressive conditional heteroskedasticity (ARCH), generalised ARCH (GARCH) models to explain volatility clustering and persistence in spot electricity prices. This is followed by a summary of works involving meanreversion, jump-diffusion and regime-switching models. Such studies investigate the speed of mean-reversion and the price jumps/spikes that result from supply and demand of a commodity with virtually no storage.

Initially, a group of papers is presented that employ Dickey-Fuller (DF), Augmented Dickey-Fuller and various non-linear models (Helm and Power, 1992; Walls, 1999; DeVany and Walls, 1999b; Robinson, 2000; Wolak, 2000; Guthrie and Videbeck, 2002; Robinson and Baniak, 2002 and Li and Flynn, (2004). This is followed by a collection of well-cited papers involving various ARCH or GARCH processes.

\section{Vector Autoregressive (VAR)}

Helm and Power (1992) produced one of the first research papers that attempts to provide an explanation of the pool pricing behaviour. Helm and Power (1992) use Dickey-Fuller (DF) and Augmented Dickey-Fuller (ADF) unit root tests on the daily pool price and demand in the British supply industry from April 1990 to August 1991. They include a dummy variable to take account of the initial expiry

date of the first contract for differences on the 22 March 1991. All series are found to be non-stationary and strongly co-integrated. A simple error correction model, with the inclusion of lagged prices, produces a reliable relationship between pool price and demand. The results indicate that in the long run, there is a change in the relationship between pool price and demand.

Walls (1999) produce the seminal work on electricity futures markets. The paper examines the effects of trading volume and time to maturity on spot price volatility for fourteen futures electricity contracts. The data involves daily data on electricity futures contracts traded on the New York Mercantile Exchange (NYMEX) for delivery at California-Oregon-Border (COB) and Palo Verde Nuclear Switchyard (PV) from 29 March 1996 to 26 November 1996. Phillips-Perron (PP) unit root tests reject the hypothesis that volatility and $\log$ of volume of trade are nonstationary, therefore standard regression techniques can be applied to these series. The results show that volatility and the estimated coefficient of maturity for a majority of the electricity contracts are significant and negative; thus are consistent with the Samuelson hypothesis that price volatility increases as the future contract approaches maturity, even with the inclusion of the log volume of trade.

Walls teamed with DeVany (DeVany and Walls, 1999b) also use the Augmented Dicky-Fuller (ADF) and Choleski variance decomposition to show daily electricity prices converge between interconnected markets; for five decentralized regional markets in western United States spanning December 1994 to April 1996. The 
results suggest that the decentralized markets and local arbitrage are able to produce a near uniform/stable price over the transmission network, thus indicating that the markets are informationally efficient. The main contribution of this paper is that it is the seminal research implementing stationarity tests and co-integration with applications to a complex deregulated commodity.

Robinson (2000) explores autoregressive models - where the pool price is regressed on lagged pool prices of period one and period six and a non-linear logistic term - to model the behaviour of pool prices in the English and Welsh wholesale electricity markets. Robinson and Baniak (2002) extend the research by introducing non-parametric tests involving distributional densities - such as the normal, logistic double exponential and Cauchy - to forecast pool prices in the English and Welsh electricity markets. Wolak (2000) also employs autoregression with eight lags and eigenvalues of the residual covariance matrix to forecast spot prices in the English, Welsh, Swedish and Norwegian, Victorian and New Zealand markets. Guthrie and Videbeck (2002) introduce high frequency, half-hourly data, in the autoregressive model, also encompassing daily and monthly dummies to assess electricity prices in New Zealand. Li and Flynn (2004) use diurnal patterns to determine if there are differences between average weekday and weekend consumption patterns in 13 deregulated markets involving Canada, US, Germany, Britain, Spain, Scandinavia, Australia and New Zealand. The daily pool prices are normalized against the average weekday price for weekday data; and the average weekend price for weekend data. North American markets exhibit a monotonic weekday peak while all other markets exhibit more than one price peak. Britain and Spain show patterns that are consistent and predictable thus enabling consumers to manage their electricity consumption. Consumers in such markets have to manage their risks through hedging mechanisms. The main contribution of these research papers lies in the application of autoregressive time-series techniques to model the pricing behaviour of deregulated electricity markets.

This group of papers forms the foundation of research into the dynamics of the wholesale electricity pricing. The unit root tests, co-integration and autoregression techniques do not take into account of the heteroskedasitic or the time-varying variances and the mean reverting and extreme jumps or spikes in spot electricity prices. These weaknesses are overcome in the next group of studies.

\section{ARCH and GARCH Models}

The following papers employ a family of autoregressive conditional heteroskedastistic models (ARCH). To begin with, Robinson and Taylor (1998) use daily returns of electricity company share prices from 10 December 1990 to 11 March 1996 to measure volatility changes in twelve UK regional electricity companies (RECs) before and after an unexpected intervention by the electricity regulator, on 7 March 1995. A simple autoregressive conditional heteroskedastistic (ARCH) model includes a dummy variable to reflect the time of the regulator's intervention on 7 March, 1995 (spike) in the mean equation and also a dummy variable to represent the subsequent period from 3 March 1995 (shift in volatility) to the conditional variance equation. In the conditional mean equation, the impulse effect of the regulatory intervention on the 7 March 1995 is negative and significant in all twelve markets. This indicates a large fall in share prices of the RECs on the announcement of the intervention. For the conditional variance equation, the 
estimated coefficients for the ARCH term demonstrate a significant level of persistence in ten of the RECs. The results indicate a significant estimated coefficient of the dummy variable for eight of the twelve markets. This demonstrates that the conditional variance has found a new level. The main contribution of this study lies in the inclusion of dummy variables to take account of regulatory intervention in the conditional mean and variance equations of the ARCH process. This research is the leading work using the ARCH process to measure volatility in the spot electricity market.

Solibakke (2002) studies the characteristics of the daily price changes of the System Price of the Nordic spot electricity power market, spanning October 1992 to January 2000. This is the first study that analyses the conditional mean and variance equations by taking account of the deviation from the normal distribution in spot price series. Solibakke (2002) initially estimates the conditional mean equation using the $\log$ first difference of the daily spot price in the Nordic spot electricity market being adjusted for day-of-week and month-of-year effects. The log of the squared residuals from the conditional mean equation is used to estimate the conditional variance equation, which once again is adjusted for calendar effects. The results of the conditional mean show significant price change patterns over the week with high power usage on Mondays and lower usage on Saturday but with no significant monthly patterns. By contrast, there is evidence of both day-of-week and month-ofyear effects in the conditional variance equation. The main contribution of this paper lies in the incorporation of asymmetric and fat-tailed characteristics to assess the spot electricity prices.

Goto and Karolyi (2003) employ univariate jump reverting and GARCH processes with and without time dependency to analyze the multiple regional trading areas in the deregulated electricity markets, namely: US, NordPool and Australia. Daily peak spot prices for eight trading areas in the US span from 24 April 1998 to December 2002. The NordPool data cover nine trading areas spanning January 1993 to December 2002. The Australian data for five trading areas is from December 1998 to December 2002. Goto and Karolyi (2003) show that the GARCH models with seasonally time dependent jumps are significant in modelling price volatility in all regional markets for the US, Nordic and Australian electricity markets. This study differs from the previous studies by including a time dependent component in the GARCH process.

Hadsell et al. (2004) model the volatility of the wholesale electricity prices of five major American markets, namely: California-Oregon Border (COB); Palo Verde; Cinergy; Entergy; and Pennsylvania-New Jersey-Maryland (PJM), covering the period from May 1996 to September 2001. A threshold autoregressive conditional heteroskedastistic (TARCH) model which incorporates an asymmetric factor to take account of the different effects of positive errors (good news) and negative errors (bad news) on the conditional variance equation is used to investigate the volatility dynamics of these markets. It is hypothesized that the occurrence of negative return (bad news) will increase volatility more than positive return (good news) of the same magnitude. Hadsell et al. (2004) also incorporate seasonal effects to take account of the monthly variations in the conditional variance equation of the TARCH model. No consistent seasonal patterns are found in the seasonal effects. This paper examines the important differences in the wholesale price volatility of five American electricity markets with respect to not only the ARCH, GARCH and degree of 
persistence but also asymmetric properties and seasonal effects. The paper uses the TARCH process including asymmetry and month-of-year effects to model the daily spot returns.

Higgs and Worthington (2005) investigate the intraday price volatility process in four Australian wholesale electricity markets; namely New South Wales, Queensland, South Australia and Victoria. The data set consists of half-hourly electricity prices and demand volumes over the period 1 January 2002 to 1 June 2003. A range of processes including GARCH, RiskMetrics, normal Asymmetric Power ARCH or APARCH, Student APARCH and skewed Student APARCH are used to model the time-varying variance in prices and the inclusion of news arrival as proxied by the contemporaneous volume of demand, time-of-day, day-of-week and month-of-year effects as exogenous explanatory variables. For the skewed Student APARCH specification, Higgs and Worthington (2005) conclude that the skewed Student APARCH model, which takes account of right skewed and fat tailed characteristics, produces the best results in all four markets. The estimated asymmetric volatility response coefficients to market news in the skewed Student model are significant and negative for all markets indicating that positive shocks (good news) are associated with higher volatility than negative shocks (bad news). Higgs and Worthington (2005) conclude that the power coefficients for the four Australian regional markets are all significantly different from two and one, thus indicating it is more appropriate to model a non-linear conditional standard deviation equation. The tail coefficients in the skewed Student APARCH specification are also significant for the four markets representing that the skewed Student distribution has again taken account of the fat right skewed characteristic of all series. Higgs and Worthington (2005) extend the above studies by taking account not only of the skewed and fat-tailed characteristics; but also the non-linearity of the conditional variance component of the spot price series.

Chan and Gray (2006) assess value at risk (VaR) in five international spot electricity markets: Victoria (Australia), NordPool (Scandinavia), Alberta (Canada), Haywood (New Zealand) and PJM (US) using variations of exponential GARCH $(\mathrm{EGARCH})$ processes. The EGARCH specification including the extreme value theory (EVT) produces the most accurate out-of-sample forecast of VaR for all five international spot electricity markets. The results of the EGARCH-EVT model show that the lagged returns are significant in the mean equation and the EGARCH process captures the conditional volatility clustering, asymmetric and day-of-week effects. The EVT component features the fat-tailed characteristics of the standardised residuals.

Koopman et al. (2007) extend the GARCH model by including the dynamics of long memory characteristics by applying periodic seasonal autoregressive fractionally integrated moving average (ARFIMA) to the disturbance term. Daily log spot prices are used to model four European markets: NordPool, EEX in Germany, Powernext in France and APX in the Netherlands. Koopman et al. (2007) also include supply and demand variables in the conditional mean equation. Weekly Monday's water reservoir levels in both demand levels and demeaned weekly differences are used as proxies for supply effects. The demand variable is obtained from daily levels, daily differences and lagged daily differences of demeaned log demand. The ARFIMA GARCH model including supply and demand effects indicates the spot electricity prices of the NordPool are more persistent than the other three European spot 
electricity markets. This study improves on previous studies by including long memory characteristics in the dynamics of the spot electricity prices.

This group of literature review is based on stationary time series and univariate techniques to profile the intra-relationship of spot electricity markets. The main feature is an appraisal of research using a variety of stationarity tests, vector autoregressive (VAR), autoregressive conditional heteroskedasticity (ARCH), generalised ARCH $(\mathrm{GARCH})$ models to explain volatility clustering and persistence in the spot electricity price series. Such studies do not investigate the speed of meanreversion and the price jumps/spikes that result from supply and demand of a commodity with virtually no storage. The next section focuses on a survey of works involving mean-reversion, jump-diffusion and regime-switching models.

\section{Mean Reversion and Regime-switching Models}

Some researchers argue that models for electricity pricing should encompass time-varying volatility and jumps in the electricity prices (Deng, 2000; Knittel and Roberts, 2001 and Escribano et al., 2002). As Goto and Karolyi (2003) point out, when demand for electricity increases, which in turn pushes up prices, there are greater incentives for more expensive generators to enter into the supply side, so some degree of mean-reversion is expected. The following collection of research takes account of jumps, spikes and mean-reversion in the spot electricity markets.

Deng (2000) extends the commonly used Ornstein-Uhlenbeck mean-reversion process, which is borrowed from financial economics to assess the dynamics of spot electricity prices. Deng (2000) observes that the spot prices can be considered as a state variable or as a function of several state variables and can be suitably modeled by jumps and stochastic volatility processes. The change in price is a function of the deviation of the price from equilibrium (which consists of the long-run average price and the rate of mean-reversion) and a random volatility or jump intensity component (involving a standard Wiener process). This basic model is extended to a time-varying model by including systematic variations such as time-of-day and seasonal effects in the mean-reversion component. Using a number of models and assumptions (including mean-reversion, jump-diffusion and regime-switching), Deng (2000) aims to more accurately reflect the physical characteristics of electricity in commodity spot price behaviour models as a first step in applying a real options approach to valuing physical assets in the electricity industry. Deng (2000) demonstrates that the mean-reversion jump-diffusion models of the energy spot prices can be used to explain the high levels of implied volatility in the market prices of traded electricity options in the US markets.

The study by Lucia and Schwartz (2001) uses the dynamics of spot prices to calculate the valuation of a contract price. This study is important as it aims to predict the systematic behaviour of electricity prices over time by incorporating changes in demand (due to economic activity) and periodic behaviour of consumption (due to climatic conditions as explanatory variables). Lucia and Schwartz (2001) apply one and two factor mean diffusion stochastic process models in the context of the deregulated Norwegian spot electricity market with an emphasis on the relationship between spot and derivative electricity prices. The one factor model is represented by the deterministic function over time and a diffusion stochastic process. The two factor model extends on the one factor model by adding a short-term mean-reverting component and a long-term equilibrium price. 
An important implication of adding the second factor is that changes in prices of the future contracts at different maturities are not perfectly correlated. This is in contrast with the one factor model.

Using a sample of daily spot prices from 1 January 1993 to December 1999, Lucia and Schwartz (2001) evaluate the parameters of the deterministic functions then use these parameter estimates to value derivative contracts. The results generally reveal that the seasonal patterns play an important role in evaluating the spot pricing behaviour. There is different volatility between summer and winter seasons. The models also exhibit a significant mean-reverting diffusion process. Their study differs from that of Deng (2000) by including a second factor in the stochastic process.

Knittel and Roberts (2001) use various models to analyze the Northern California electricity market, such as: the mean reversion; time varying mean reversion; jump diffusion; time varying jump diffusion processes; an autoregressive moving average (ARMA) model; and an exponential autoregressive conditional heteroscedastistic (EGARCH) model. A sample of 21,216 half-hourly observations, spanning 1 April 1998 to 30 August 2000, is used to examine the distributional and temporal (peak, off-peak, weekday, weekends and four seasons) patterns of the deregulated electricity prices. A mean-reverting process captures the autocorrelation present in the price series but ignores the temporal patterns. The time-varying mean-reverting model, which includes the intraday, weekend or weekday and seasonal effects, improves on the previous model but still fails to forecast the erratic nature of the price series. The jump diffusion model which attempts to incorporate the leptokurtic nature of the price series and the jump diffusion time varying model show a significant increase in the probability of a jump but the reliability of these models according to the root mean squared forecast errors is very poor. Finally, the EGARCH process is estimated to take account of how news innovations could have an asymmetric impact on the price volatility. The ARCH and GARCH effects are significant thus indicating a high degree of persistence. The estimated asymmetric effect is significant and positive, thus suggesting the process of an 'inverse leverage effect'. This implies that the positive shocks to spot electricity prices exacerbate the conditional variance more than negative shocks. The novelty of the Knittel and Roberts (2001) study lies in the introduction of a GARCH process to replace the stochastic component in the mean-reversion models.

Escribano et al. (2002) employ a general and flexible model to encompass the main features - such as interaction between jumps, GARCH and mean reversion behaviour of electricity prices - in six deregulated markets, namely: Argentina, Australia (Victoria), New Zealand (Heyward), Scandinavia (NordPool), Spain and the US (Pennsylvania-New Jersey-Maryland; PJM). Daily prices, expressed in local currency, cover different sample periods. The results for all six deregulated markets showed that the models with increased complexity produced improved goodness of fit (according to Schwartz Criteria) as compared to the results of the basic GARCH $(1,1)$ model. The results reinforce that the probability of observing jumps is not constant over time. In addition, various unit root tests incorporating jumps and GARCH errors are used to test the null hypothesis of nonstationarity against the alternative of stationarity or mean-reversion. The optimal models for all markets are found to be mean-reverting. The main innovation of the Escribano et al. study is to 
estimate a general and flexible model to take account of the interaction between jumps, GARCH and mean reversion behaviour of electricity prices.

Huisman and Mahieu (2003) aim to capture the mean-reverting and the extreme jumps or spikes in spot electricity prices. The spot price at any point in time can be in any one of the three different regimes: a normal regime with a mean-reverting component; an abnormal regime with price jumps or spikes also with a meanreverting component; and a regime that measures the return to normal regime from the abnormal regime. Huisman and Mahieu (2003) assume that spikes return to the normal regime after one day. A regime-switching model is used to identify price spikes separately from the normal regime for the Dutch APX, German LPX and the UK markets. The results show that the mean-reversion is stronger just after the periods in which the spikes occur, than during the normal period. This shows that the spikes are short-lived. This study adds to the previous studies which use stochastic jumps to model spikes in that previous studies do not take account of the fact that the price spikes are short-lived.

Bierbrauer et al. (2004), de Jong and Huisman (2002), de Jong (2005) and Mount et al. (2006) extend on the research by Huisman and Mahieu (2003) which makes no allowance for consecutive spikes and time varying transition probability that may arise. Bierbrauer et al. (2004), de Jong and Huisman (2002) and de Jong (2005) propose a two-regime model that permits a spike regime of lognormal prices with consecutive spikes. Huisman and Mahieu's (2003) regime-switching model assumes that the transition probabilities are constant. In reality, these transition probabilities could vary according to demand and weather conditions, amongst other things. Mount et al. (2006) overcome this limitation by providing a new regime-switching model that allows the transition probabilities to be state-dependent by including load and/or the implicit load margin.

The main advantage of studies using stochastic, mean-reverting and Markov regime-switching models to examine the price dynamics in wholesale electricity spot markets fully is these models take into account of the high volatility, mean-reversion and spike-prone characteristic of electricity markets. The main limitation of these studies is the rather restrictive assumption regarding the irregular spiking behaviour.

\section{CONCLUSIONS}

Better understanding of the dynamics of electricity pricing is likely to throw light on the efficiency of pricing and the impact of interconnection within the centralized markets still primarily composed of commercialized and corporatized public sector entities. A fuller understanding of the pricing relationships between these markets enables the benefits of interconnection to be assessed as a step towards the fuller integration of the regional electricity markets into a national electricity market. This provides policy inputs into both the construction of new interconnectors and the preparation of guidelines for the reform of existing market mechanisms.

The limitations of this literature review indicate a number of areas where future research could be usefully applied. First, the frequency of data has a bearing on the estimation of the price and volatility relationships in the spot electricity markets. From the review, only four of 26 research papers (15 percent) employ half-hourly data. In this regard, the price and volatility relationships within and between regional markets could be under or overstated through misspecification in the data. Future 
research should take account of high frequency data by employing half-hourly or hourly data rather than daily data, with the objective of improving the robustness of the MGARCH, regime switching and market efficiency models.

Second, the majority of research papers show that not nearly all spot markets are informationally efficient. As additional data come to hand, further privatization of the electricity industry may be advocated in order to enhance efficiency. These efficiency gains would ultimately benefit consumers resulting in lower prices and higher quality output. As the market mechanism continues to change where spot regional markets further embrace privatization to promote competition, a natural extension over time is to include ownership or market structure of each regional market to investigate spot price trends. Third, another limitation lies in the fact that a majority of research papers entail univariate estimation. With the introduction of new interconnectors, it would be appropriate to examine the dynamics of the interrelationship or dynamics between spot electricity markets. While it may potentially extend to the multivariate context, the univariate analyses are already very complex, so this remains a challenging topic for future research.

Finally, another extension would be to examine the conditions whereby generators are argued to exercise market power through increasing prices by withholding capacity at times of high demand. Market power may be used to explain at least some of the large increases in the wholesale prices of electricity at some times. Empirical evidence to support a presumption of high prices relating the withholding of supplies from the market by suppliers can be based on the competitive benchmark analysis similar to that of Joskow and Kahn (2002) for the Californian spot electricity market. The competitive price benchmark is the shortrun marginal cost of supplying electricity from the last unit that clears the market in each hour. Comparing the realized price with the marginal supply cost is a widely acceptable method of measuring the presence of market power. This is useful for examining prices in commodity markets with homogenous products such as spot electricity markets.

However, some departures from ideal competitive conditions do not necessarily imply there is market power of any policy concern. Many markets that are not subject to price controls are imperfectly competitive. Any empirical analysis of pricing behaviour is subject to some degree of uncertainty. The price may depart from the observed marginal cost even in a perfectly competitive market to reflect real capacity constraints and opportunity costs associated with inter-temporal production limits on generators. However, this approach quantifies the extent to which realized market prices can depart from the competitive benchmark prices and provides a useful metric, along with the analysis of withholding behaviour that policy makers can use to judge whether the gap between the competitive benchmark prices and the actual prices is so large that regulatory intervention is justified (Joskow and Kahn, 2002).

\section{ACKNOWLEDGEMENTS}

The authors would like to thank the editor-in-chief (Dean Mountain) and an anonymous reviewer for helpful comments on an earlier version of this paper. 
Table 1. Summary of electricity price modeling studies

\begin{tabular}{|c|c|c|c|c|c|c|}
\hline Author(s) & $\begin{array}{l}\text { Study } \\
\text { objective(s) }\end{array}$ & Sample & $\begin{array}{l}\text { Dependent } \\
\text { Variable }\end{array}$ & $\begin{array}{l}\text { Independent } \\
\text { Variables }\end{array}$ & Technique(s) & Main Findings \\
\hline $\begin{array}{l}\text { Helm and } \\
\text { Powell } \\
(1992)\end{array}$ & $\begin{array}{l}\text { Analyze pool } \\
\text { pricing } \\
\text { behaviour with } \\
\text { reference to } \\
\text { underlying } \\
\text { hedging } \\
\text { contracts }\end{array}$ & $\begin{array}{l}\text { Daily average } \\
\text { pool price in the } \\
\text { British } \\
\text { electricity } \\
\text { supply industry } \\
\text { from April } 1990 \\
\text { to August } 1991\end{array}$ & $\begin{array}{l}\text { Log daily } \\
\text { eaverage pool } \\
\text { price }\end{array}$ & $\begin{array}{l}\text { Log daily demand; } \\
\text { dummy variable to } \\
\text { take account of } \\
\text { structural break } \\
\text { when contract for } \\
\text { differences a form } \\
\text { of options contract } \\
\text { expired; lagged log } \\
\text { daily demand; and } \\
\text { lagged log daily } \\
\text { pool price }\end{array}$ & $\begin{array}{l}\text { Dickey-Fuller and } \\
\text { augmented Dickey- } \\
\text { Fuller stationarity } \\
\text { tests, co-integration } \\
\text { analysis, error } \\
\text { correction models. }\end{array}$ & $\begin{array}{l}\text { The non-stationary } \\
\text { series are strongly } \\
\text { co-integrated, even } \\
\text { with the inclusion of } \\
\text { a dummy variable } \\
\text { to take account of } \\
\text { structural breaks. } \\
\text { When the lagged } \\
\text { price is included, } \\
\text { the error correction } \\
\text { model exhibits } \\
\text { evidence of ARCH } \\
\text { effects. }\end{array}$ \\
\hline $\begin{array}{l}\text { Robinson } \\
\text { and Taylor } \\
\text { (1998) }\end{array}$ & $\begin{array}{l}\text { Use } \\
\text { conditional } \\
\text { variance to } \\
\text { measure the } \\
\text { effects of } \\
\text { regulatory } \\
\text { intervention in } \\
\text { regional } \\
\text { electricity } \\
\text { companies }\end{array}$ & $\begin{array}{l}\text { Daily stock } \\
\text { price changes } \\
\text { in } 12 \text { UK } \\
\text { regional } \\
\text { electricity } \\
\text { companies from } \\
10 \text { December } \\
1990 \text { to } 11 \\
\text { March } 1996\end{array}$ & $\begin{array}{l}\text { Stock price } \\
\text { changes for } \\
\text { conditional } \\
\text { mean } \\
\text { equation and } \\
\text { nvolatility for } \\
\text { conditional } \\
\text { variance } \\
\text { equation }\end{array}$ & $\begin{array}{l}\text { Two dummies for } \\
\text { unexpected } \\
\text { interventions by } \\
\text { electricity regulator } \\
\text { in March } 1995\end{array}$ & $\begin{array}{l}\text { Autoregressive } \\
\text { Conditional } \\
\text { Heteroskedasticity } \\
\text { process of order } \\
\text { one - ARCH(1) }\end{array}$ & $\begin{array}{l}\text { The conditional } \\
\text { variance equations } \\
\text { indicate that ten of } \\
\text { the twelve regional } \\
\text { markets exhibit } \\
\text { significant } \\
\text { persistence and } \\
\text { eight markets show } \\
\text { increased volatility } \\
\text { after regulatory } \\
\text { intervention. }\end{array}$ \\
\hline Walls (1999) & $\begin{array}{l}\text { Measure } \\
\text { volatility of } \\
\text { electricity } \\
\text { future } \\
\text { contracts as } \\
\text { they approach } \\
\text { maturity }\end{array}$ & $\begin{array}{l}\text { Daily data on } \\
\text { electricity } \\
\text { futures } \\
\text { contracts } \\
\text { traded on the } \\
\text { New York } \\
\text { Mercantile } \\
\text { Exchange } \\
\text { (NYMEX) for } \\
\text { California- } \\
\text { Oregon-Border } \\
\text { (COB) and Palo } \\
\text { Verde Nuclear } \\
\text { Switchyard } \\
\text { (PV) from } 29 \\
\text { March } 1996 \text { to } \\
26 \text { November } \\
1996\end{array}$ & $\begin{array}{l}\text { Volatility } \\
\text { measured by } \\
\text { high/low } \\
\text { variance }\end{array}$ & $\begin{array}{l}\text { Model (1) Log of } \\
\text { maturity being the } \\
\text { number of trading } \\
\text { days until the } \\
\text { futures contract } \\
\text { expires; Model (2) } \\
\text { Log of maturity and } \\
\text { log of volume being } \\
\text { the number of } \\
\text { futures contracts } \\
\text { traded on the } \\
\text { particular day for } \\
\text { seven different } \\
\text { maturity dates for } \\
\text { each market }\end{array}$ & $\begin{array}{l}\text { Philips and Perron } \\
\text { unit root tests, } \\
\text { regression analysis. }\end{array}$ & $\begin{array}{l}\text { Volatility and log } \\
\text { volumes are both } \\
\text { stationary. Model } \\
\text { (1) shows that the } \\
\text { results are } \\
\text { consistent with the } \\
\text { Samuelson } \\
\text { hypothesis that } \\
\text { price volatility } \\
\text { increases as the } \\
\text { future contract } \\
\text { approaches } \\
\text { maturity. The } \\
\text { results of Model (2) } \\
\text { illustrate strong } \\
\text { evidence of } \\
\text { increasing volatility } \\
\text { as contract maturity } \\
\text { approaches, even } \\
\text { with the inclusion of } \\
\text { volume of trade. }\end{array}$ \\
\hline $\begin{array}{l}\text { De Vany ar } \\
\text { Walls } \\
(1999 a)\end{array}$ & $\begin{array}{l}\text { dExamine the } \\
\text { behaviour of } \\
\text { peak and off- } \\
\text { peak electricit } \\
\text { spot prices for } \\
\text { evidence of } \\
\text { market } \\
\text { integration }\end{array}$ & $\begin{array}{l}\text { Peak and off- } \\
\text { peak daily } \\
\text { electricity prices } \\
\text { from December } \\
1994 \text { to April } \\
1996 \text { for } 11 \\
\text { regional } \\
\text { markets in the } \\
\text { western US }\end{array}$ & $\begin{array}{l}\text { Spot price for } \\
\text { each market }\end{array}$ & $\begin{array}{l}\text { Prices of } \\
\text { interconnected } \\
\text { markets }\end{array}$ & $\begin{array}{l}\text { Augmented Dickey- } \\
\text { Fuller unit root } \\
\text { tests, co-integration } \\
\text { analysis between } \\
\text { fifty-five market } \\
\text { pairs. }\end{array}$ & $\begin{array}{l}\text { All electricity prices, } \\
\text { except one are non- } \\
\text { stationary. All off- } \\
\text { peak market pairs } \\
\text { are co-integrated, } \\
\text { and eighty-seven } \\
\text { percent of the peak } \\
\text { demand market } \\
\text { pairs are co- } \\
\text { integrated. }\end{array}$ \\
\hline
\end{tabular}




\begin{tabular}{|c|c|c|c|c|c|c|}
\hline$\overline{\text { Author(s) }}$ & $\begin{array}{l}\text { Study } \\
\text { objective(s) }\end{array}$ & Sample & $\begin{array}{l}\text { Dependent } \\
\text { Variable }\end{array}$ & $\begin{array}{l}\text { Independent } \\
\text { Variables }\end{array}$ & Technique(s) & Main Findings \\
\hline $\begin{array}{l}\text { De Vany an } \\
\text { Walls } \\
(1999 b)\end{array}$ & $\begin{array}{l}\text { dEstimate } \\
\text { dynamic } \\
\text { equations of } \\
\text { wholesale or } \\
\text { spot prices } \\
\text { over } \\
\text { decentralised } \\
\text { state regions }\end{array}$ & $\begin{array}{l}\text { Peak and off- } \\
\text { peak daily } \\
\text { electricity price } \\
\text { from Decembe } \\
1994 \text { to April } \\
1996 \text { for five } \\
\text { regional } \\
\text { markets in } \\
\text { western US }\end{array}$ & $\begin{array}{l}\text { First } \\
\text { difference of } \\
\text { sspot price } \\
\end{array}$ & Lagged spot price & $\begin{array}{l}\text { Vector } \\
\text { Autoregressive } \\
\text { models; and } \\
\text { Choleski } \\
\text { decomposition to } \\
\text { identify impulse } \\
\text { responses }\end{array}$ & $\begin{array}{l}\text { A larger proportion } \\
\text { of peak period } \\
\text { shocks than off- } \\
\text { peak period shocks } \\
\text { transmit from the } \\
\text { originating market } \\
\text { node to other more } \\
\text { distant } \\
\text { interconnecting } \\
\text { market nodes. The } \\
\text { damped responses } \\
\text { of the price shocks } \\
\text { and the stable } \\
\text { forecast errors } \\
\text { suggest regional } \\
\text { markets in western } \\
\text { US are efficient. }\end{array}$ \\
\hline Deng (2000 & $\begin{array}{l}\text { Examine a } \\
\text { broad class of } \\
\text { stochastic } \\
\text { processes to } \\
\text { model } \\
\text { electricity spot } \\
\text { prices and how } \\
\text { these } \\
\text { processes can } \\
\text { impact on the } \\
\text { value and } \\
\text { optimal timing } \\
\text { of investment } \\
\text { opportunities }\end{array}$ & US markets & $\begin{array}{l}\text { Natural log of } \\
\text { spot electricity } \\
\text { price and spo } \\
\text { price of } \\
\text { generating } \\
\text { fuel s, such as } \\
\text { natural gas }\end{array}$ & $\begin{array}{l}\text { Jumps; and } \\
\text { stochastic volatility }\end{array}$ & $\begin{array}{l}\text { Mean-reversion, } \\
\text { jump-diffusion, and } \\
\text { regime-switching }\end{array}$ & $\begin{array}{l}\text { The mean-reversion } \\
\text { jump-diffusion } \\
\text { models are reliable } \\
\text { to model the } \\
\text { volatility in the } \\
\text { market prices of the } \\
\text { traded electricity } \\
\text { options in the US } \\
\text { markets. }\end{array}$ \\
\hline
\end{tabular}

Robinson Model the Daily average Pool purchasePool purchase price Autoregressive The nonlinear (2000) behaviour of pool price from price lagged one period; regression including model is superior in spot electricity 1 April 1990 to and lagged six a non-linear logistic estimating the pool prices which 31 May 1996 can influence for the English the contract and Welsh prices wholesale electricity markets periods term price behaviour. The estimated parameters imply that prices are less mean reverting the further they deviate from the mean.

Wolak

Forecast daily Half hourly spot The mean of vector prices inprices for all all 48 half England and markets with hour spot Wales; the exception of prices and the Sweden and hourly prices formean of all 24 Norway; the Sweden hourly spot Victoria in and Norway prices for the Australia; and electricity Sweden and New Zealand market Norway spot electricity market markets

\begin{tabular}{|c|c|c|}
\hline $\begin{array}{l}\text { Eight lags of this } \\
\text { price; and all other } \\
\text { half-hourly prices }\end{array}$ & $\begin{array}{l}\text { Autoregressive } \\
\text { models; and } \\
\text { eigenvalues of the } \\
\text { residual covariance } \\
\text { matrix from the } \\
\text { autoregressive } \\
\text { model }\end{array}$ & $\begin{array}{l}\text { The dynamics of } \\
\text { the within-day } \\
\text { variation in prices is } \\
\text { more complex in } \\
\text { the Victorian } \\
\text { market, while the } \\
\text { Nordic market has } \\
\text { the least } \\
\text { complexity. The } \\
\text { NordPool prices are } \\
\text { the most } \\
\text { forecastable. }\end{array}$ \\
\hline
\end{tabular}




\begin{tabular}{|c|c|c|c|c|c|c|}
\hline$\overline{\text { Author(s) }}$ & $\begin{array}{l}\text { Study } \\
\text { objective(s) }\end{array}$ & Sample & $\begin{array}{l}\text { Dependent } \\
\text { Variable }\end{array}$ & $\begin{array}{l}\text { Independent } \\
\text { Variables }\end{array}$ & Technique(s) & Main Findings \\
\hline $\begin{array}{l}\text { Knittel and } \\
\text { Roberts } \\
\text { (2001) }\end{array}$ & $\begin{array}{l}\text { Model the } \\
\text { degree of } \\
\text { persistence, } \\
\text { intraday and } \\
\text { seasonal } \\
\text { effects in } \\
\text { electricity } \\
\text { prices }\end{array}$ & $\begin{array}{l}\text { Hourly } \\
\text { electricity prices } \\
\text { from } 1 \text { April } \\
1998 \text { to } 30 \\
\text { August } 2000 \text { for } \\
\text { one Californian } \\
\text { electricity } \\
\text { market }\end{array}$ & $\begin{array}{l}\text { Change in half } \\
\text { shourly prices }\end{array}$ & $\begin{array}{l}\text { fDemand; time-of- } \\
\text { day; day-of-week; } \\
\text { and seasonal } \\
\text { effects }\end{array}$ & $\begin{array}{l}\text { Mean reversion } \\
\text { model; time varying } \\
\text { mean reversion; } \\
\text { jump diffusion } \\
\text { process; univariate } \\
\text { Markov process; } \\
\text { exponential GARCH } \\
\text { (EGARCH) }\end{array}$ & $\begin{array}{l}\text { Electricity prices } \\
\text { exhibit a high } \\
\text { degree of } \\
\text { persistence with a } \\
\text { significant } \\
\text { relationship } \\
\text { tbetween demand, } \\
\text { intraday, day-of- } \\
\text { week and seasonal } \\
\text { effects. The } \\
\text { EGARCH model } \\
\text { demonstrates a } \\
\text { significant inverse } \\
\text { leverage effect } \\
\text { indicating positives } \\
\text { price shocks } \\
\text { increase price } \\
\text { volatility. }\end{array}$ \\
\hline $\begin{array}{l}\text { Lucia and } \\
\text { Schwartz } \\
\text { (2001) }\end{array}$ & $\begin{array}{l}\text { Model the } \\
\text { predictable } \\
\text { component in } \\
\text { the dynamics } \\
\text { of spot } \\
\text { electricity } \\
\text { prices and its } \\
\text { implications for } \\
\text { derivative } \\
\text { securities }\end{array}$ & $\begin{array}{l}\text { Daily spot } \\
\text { prices from } 1 \\
\text { January } 1993 \\
\text { to December } \\
1999 \text { for the } \\
\text { Norwegian spot } \\
\text { electricity } \\
\text { rmarket }\end{array}$ & $\begin{array}{l}\text { Log of spot } \\
\text { prices for the } \\
\text { deterministic } \\
\text { component } \\
\text { and the } \\
\text { trandom } \\
\text { fluctuation for } \\
\text { the stochastic } \\
\text { component }\end{array}$ & $\begin{array}{l}\text { Demand and } \\
\text { seasonal factors for } \\
\text { the deterministic } \\
\text { component; } \\
\text { Brownian motion in } \\
\text { the one factor } \\
\text { model and the } \\
\text { inclusion of a short- } \\
\text { term mean reverting } \\
\text { component; and a } \\
\text { long-term } \\
\text { equilibrium price in } \\
\text { the two factor model }\end{array}$ & $\begin{array}{l}\text { Diffusion stochastic } \\
\text { processes }\end{array}$ & $\begin{array}{l}\text { The seasonal } \\
\text { patterns are } \\
\text { significant in } \\
\text { modeling the } \\
\text { dynamics of spot } \\
\text { electricity prices } \\
\text { with different } \\
\text { volatility between } \\
\text { the summer and } \\
\text { winter seasons and } \\
\text { the models exhibit a } \\
\text { significant mean } \\
\text { reverting diffusion } \\
\text { process. }\end{array}$ \\
\hline
\end{tabular}

de Jong and Estimate a Daily spot Daily log Mean-reversion; Regime switching The options pricing Huisman model to value prices for the returns and regime model with normal model can be used (2002) options on Dutch spot electricity spot market (APX) prices to take spanning 2 account of two January 2001 main features to 30 June switching to and lognormal spiketo predict an explicit incorporate jumps regimes value for the spike and spikes in spot component of the electricity prices value of options on electricity spot prices where spikes have made the sale reversion and spikes. of options highly risky.

\begin{tabular}{|c|c|c|c|c|c|c|}
\hline $\begin{array}{l}\text { Escribano, } \\
\text { Pena and } \\
\text { Villaplana } \\
(2002)\end{array}$ & $\begin{array}{l}\text { Estimate a } \\
\text { general and } \\
\text { flexible model } \\
\text { to take } \\
\text { account of the } \\
\text { interaction } \\
\text { between } \\
\text { jumps, } \\
\text { GARCH and } \\
\text { mean } \\
\text { reversion } \\
\text { behaviour of } \\
\text { electricity } \\
\text { prices }\end{array}$ & $\begin{array}{l}\text { Daily electricity } \\
\text { prices in five } \\
\text { deregulated } \\
\text { markets, } \\
\text { namely: } \\
\text { Argentina; } \\
\text { Australia } \\
\text { (Victoria); New } \\
\text { Zealand } \\
\text { (Heyward); } \\
\text { Scandinavia } \\
\text { (NordPool) and } \\
\text { Spain }\end{array}$ & $\begin{array}{l}\text { Conditional } \\
\text { mean and } \\
\text { conditional } \\
\text { variance }\end{array}$ & $\begin{array}{l}\text { The stochastic } \\
\text { component consists } \\
\text { of seasonality; } \\
\text { mean reversion; } \\
\text { jumps }\end{array}$ & $\begin{array}{l}\text { Six nested GARCH } \\
\text { s models with the } \\
\text { inclusion of } \\
\text { seasonal sinusoidal } \\
\text { functions and jumps } \\
\text { with time-dependen } \\
\text { intensity in the spot } \\
\text { prices }\end{array}$ & $\begin{array}{l}\text { The electricity } \\
\text { prices for the five } \\
\text { international } \\
\text { I markets indicate } \\
\text { smean-reverting with } \\
\text { tstrong volatility with } \\
\text { jumps of time- } \\
\text { dependent intensity } \\
\text { even after adjusting } \\
\text { for seasonality. }\end{array}$ \\
\hline
\end{tabular}




\begin{tabular}{|c|c|c|c|c|c|c|}
\hline Author(s) & $\begin{array}{l}\text { Study } \\
\text { objective(s) }\end{array}$ & Sample & $\begin{array}{l}\text { Dependent } \\
\text { Variable }\end{array}$ & $\begin{array}{l}\text { Independent } \\
\text { Variables }\end{array}$ & Technique(s) & Main Findings \\
\hline $\begin{array}{l}\text { Guthrie and } \\
\text { Videbeck } \\
\text { (2002) }\end{array}$ & $\begin{array}{l}\text { Assess the } \\
\text { high frequency } \\
\text { electricity spot } \\
\text { price dynamics } \\
\text { by treating } \\
\text { electricity } \\
\text { delivered at } \\
\text { different half- } \\
\text { hour of the day } \\
\text { as different } \\
\text { commodities }\end{array}$ & $\begin{array}{l}\text { Half-hourly data } \\
\text { from two } \\
\text { sections: } 1 \\
\text { March } 2000 \text { to } \\
28 \text { February } \\
2001 \text { and } 1 \\
\text { March } 2001 \text { to } \\
28 \text { February } \\
2002 \text { for a key } \\
\text { New Zealand } \\
\text { node }\end{array}$ & $\begin{array}{l}\text { aSpot } \\
\text { electricity } \\
\text { price of each } \\
\text { half hour }\end{array}$ & $\begin{array}{l}\text { Lagged prices of its } \\
\text { own half-hour and } \\
\text { lagged prices of the } \\
\text { other half hours; } \\
\text { and daily and } \\
\text { monthly dummies }\end{array}$ & $\begin{array}{l}\text { Periodic } \\
\text { autoregression } \\
\text { models (PAR); and } \\
\text { state space models }\end{array}$ & $\begin{array}{l}\text { Forty-eight PARs } \\
\text { are estimated and } \\
\text { the spot price is } \\
\text { highly correlated } \\
\text { within these } \\
\text { markets. The } \\
\text { dynamic structure is } \\
\text { maintained by } \\
\text { introducing } \\
\text { restricted number of } \\
\text { lags. The state } \\
\text { space models using } \\
\text { intraday prices are } \\
\text { found to reliable in } \\
\text { estimating the } \\
\text { electricity market } \\
\text { structures. }\end{array}$ \\
\hline $\begin{array}{l}\text { Robinson } \\
\text { and Baniak } \\
(2002)\end{array}$ & $\begin{array}{l}\text { Illustrate that } \\
\text { generators } \\
\text { with market } \\
\text { power may } \\
\text { have } \\
\text { incentives to } \\
\text { create volatility } \\
\text { in the spot } \\
\text { market to } \\
\text { benefit from } \\
\text { higher risk } \\
\text { premia in the } \\
\text { contract } \\
\text { market }\end{array}$ & $\begin{array}{l}\text { Daily average } \\
\text { pool prices from } \\
1 \text { April } 1990 \text { to } \\
31 \text { May } 1996 \\
\text { for the English } \\
\text { and Welsh } \\
\text { electricity } \\
\text { industry }\end{array}$ & $\begin{array}{l}\text { Rank of the } \\
\text { nchange in the } \\
\text { logarithm of } \\
\text { the spot price }\end{array}$ & $\begin{array}{l}\text { Shifts in pool price } \\
\text { volatility at expiry of } \\
\text { coal contract and } \\
\text { during the period of } \\
\text { two year price cap }\end{array}$ & $\begin{array}{l}\text { Non-parametric } \\
\text { tests on densities } \\
\text { corresponding to } \\
\text { the normal; logistic; } \\
\text { double exponential; } \\
\text { and Cauchy } \\
\text { distributions }\end{array}$ & $\begin{array}{l}\text { At the expiry of the } \\
\text { coal contract, the } \\
\text { generation } \\
\text { companies have the } \\
\text { opportunity to exert } \\
\text { market power to } \\
\text { increase the level } \\
\text { and volatility of the } \\
\text { pool prices. The } \\
\text { volatility of the pool } \\
\text { price also increased } \\
\text { during the two year } \\
\text { price cap. }\end{array}$ \\
\hline $\begin{array}{l}\text { Solibakke } \\
(2002)\end{array}$ & $\begin{array}{l}\text { Model the } \\
\text { conditional } \\
\text { mean and } \\
\text { variance of the } \\
\text { spot electricity } \\
\text { price as it is } \\
\text { the underlying } \\
\text { instrument for } \\
\text { derivatives in } \\
\text { the electricity } \\
\text { market. }\end{array}$ & $\begin{array}{l}\text { Daily spot price } \\
\text { in the Nordic } \\
\text { spot electricity } \\
\text { market from } \\
\text { October } 1992 \\
\text { to January } \\
2000\end{array}$ & $\begin{array}{l}\text { Log first } \\
\text { difference of } \\
\text { the daily spot } \\
\text { price }\end{array}$ & $\begin{array}{l}\text { Day-of-week and } \\
\text { month-of-year } \\
\text { effects in the } \\
\text { conditional mean } \\
\text { equation; and also } \\
\text { in the conditional } \\
\text { variance equation }\end{array}$ & $\begin{array}{l}\text { Asymmetric } \\
\text { GARCH } \\
\text { (AGARCH); } \\
\text { truncated GARCH; } \\
\text { and EGARCH }\end{array}$ & $\begin{array}{l}\text { The truncated } \\
\text { GARCH and } \\
\text { asymmetric } \\
\text { GARCH (AGARCH) } \\
\text { processes out } \\
\text { performed the } \\
\text { exponential model } \\
\text { and these } \\
\text { processes were } \\
\text { significant in } \\
\text { modeling the } \\
\text { electricity dynamics. }\end{array}$ \\
\hline
\end{tabular}




\begin{tabular}{|c|c|c|c|c|c|c|}
\hline$\overline{\text { Author(s) }}$ & $\begin{array}{l}\text { Study } \\
\text { objective(s) }\end{array}$ & Sample & $\begin{array}{l}\text { Dependent } \\
\text { Variable }\end{array}$ & $\begin{array}{l}\text { Independent } \\
\text { Variables }\end{array}$ & Technique(s) & Main Findings \\
\hline $\begin{array}{l}\text { Bystrom } \\
\text { (2003) }\end{array}$ & $\begin{array}{l}\text { Alternative } \\
\text { estimation of } \\
\text { different } \\
\text { minimum } \\
\text { variance } \\
\text { hedge ratio } \\
\text { which } \\
\text { determines } \\
\text { how many } \\
\text { futures } \\
\text { contracts } \\
\text { should be } \\
\text { bought or sold } \\
\text { for each spot } \\
\text { contract to } \\
\text { minimize the } \\
\text { variance of the } \\
\text { return portfolio }\end{array}$ & $\begin{array}{l}\text { Daily spot and } \\
\text { future prices } \\
\text { from NordPool } \\
\text { from } 2 \text { January } \\
1996 \text { to } 21 \\
\text { October } 1999\end{array}$ & $\begin{array}{l}\text { Daily spot an } \\
\text { futures return }\end{array}$ & $\begin{array}{l}\text { d Lagged spot and } \\
\text { sfutures returns in } \\
\text { the conditional } \\
\text { mean; and } \\
\text { conditional variance } \\
\text { equations }\end{array}$ & $\begin{array}{l}\text { A naive or one-to- } \\
\text { one hedge ratio; } \\
\text { OLS-hedge ratio; } \\
\text { bivariate constant } \\
\text { conditional } \\
\text { correlation GARCH; } \\
\text { and Orthogonal } \\
\text { GARCH with time } \\
\text { varying correlation }\end{array}$ & $\begin{array}{l}\text { The out-of-sample } \\
\text { forecasts show that } \\
\text { the simple OLS- } \\
\text { hedge ratio is more } \\
\text { successful in } \\
\text {; reducing the } \\
\text { portfolio variance } \\
\text { than the more } \\
\text { complex conditional } \\
\text { GARCH or } \\
\text { Orthogonal GARCH } \\
\text { hedge ratios. }\end{array}$ \\
\hline $\begin{array}{l}\text { Goto and } \\
\text { Karolyi } \\
(2003)\end{array}$ & $\begin{array}{l}\text { Examine } \\
\text { volatility } \\
\text { dynamics } \\
\text { across hubs } \\
\text { within each } \\
\text { market }\end{array}$ & $\begin{array}{l}\text { Daily average } \\
\text { prices for the } \\
\text { US ( } 8 \text { markets), } \\
\text { NordPool ( } 9 \\
\text { markets) and } \\
\text { Australia (5 } \\
\text { markets) of } \\
\text { varying lengths }\end{array}$ & $\begin{array}{l}\text { Returns in } \\
\text { the condition } \\
\text {, mean } \\
\text { equation }\end{array}$ & $\begin{array}{l}\text { Demand; seasonal } \\
\text { leffects }\end{array}$ & $\begin{array}{l}\text { GARCH without } \\
\text { jumps and include } \\
\text { seasonality; } \\
\text { GARCH with jumps } \\
\text { but no time } \\
\text { dependent intensity; } \\
\text { and GARCH with } \\
\text { time-dependent } \\
\text { jumps }\end{array}$ & $\begin{array}{l}\text { The ARCH model } \\
\text { with time- } \\
\text { dependent jumps } \\
\text { best explains the } \\
\text { price volatility } \\
\text {;features in all } \\
\text { regional markets } \\
\text { across three } \\
\text { countries. The } \\
\text { degree of } \\
\text { persistence; implied } \\
\text { probabilities; and } \\
\text { jump intensities are } \\
\text { similar in spite of } \\
\text { different factors } \\
\text { influencing supply } \\
\text { and demand. }\end{array}$ \\
\hline
\end{tabular}

Huisman Model spot Daily electricity Natural log of The deterministic Mean reversion; The results show and Mahieu electricity price prices for the spot prices for equation is and Markov regime that the mean (2003) spikes using a Dutch APX, the explained by switching models to reversion is regime German LPX deterministic dummy variables forseparate the normal stronger after the switching and UK equation and Saturday and and spike periods periods in which the model markets with the stochastic Sunday. The spikes occur than separate from different time changes in stochastic equation during the normal the mean spans the spot is a function of period. This implies reversion prices for the mean reversion; process stochastic volatility; jumps and that the spikes are stochastic volatility; jumps and short-lived. 


\begin{tabular}{|c|c|c|c|c|c|c|}
\hline Author(s) & $\begin{array}{l}\text { Study } \\
\text { objective(s) }\end{array}$ & Sample & $\begin{array}{l}\text { Dependent } \\
\text { Variable }\end{array}$ & $\begin{array}{l}\text { Independent } \\
\text { Variables }\end{array}$ & Technique(s) & Main Findings \\
\hline $\begin{array}{l}\text { Hadsell, } \\
\text { Marathe anc } \\
\text { Shawky } \\
(2004)\end{array}$ & $\begin{array}{l}\text { Measure } \\
\text { regional } \\
\text { similarity and } \\
\text { differences in } \\
\text { volatility } \\
\text { between five } \\
\text { US spot } \\
\text { electricity } \\
\text { markets }\end{array}$ & $\begin{array}{l}\text { Daily spot } \\
\text { electricity prices } \\
\text { spanning May } \\
1996 \text { to } \\
\text { September } \\
2001 \text { for five } \\
\text { major American } \\
\text { markets, } \\
\text { namely: } \\
\text { California- } \\
\text { Oregon Border } \\
\text { (COB); Palo } \\
\text { Verde; Cinergy; } \\
\text { Entergy; and } \\
\text { Pennsylvania- } \\
\text { New Jersey- } \\
\text { Maryland (PJM) }\end{array}$ & $\begin{array}{l}\text { Log of the } \\
\text { sdifference of } \\
\text { the pool } \\
\text { prices } \\
\text { (returns) in } \\
\text { the conditional } \\
\text { imean and } \\
\text { volatility in the } \\
\text { conditional } \\
\text { variance }\end{array}$ & $\begin{array}{l}\text { Monthly seasonal } \\
\text { effects; and an } \\
\text { asymmetric factor to } \\
\text { take account of the } \\
\text { different effects of } \\
\text { alpositive errors } \\
\text { (good news) and } \\
\text { negative errors (bad } \\
\text { news) on the } \\
\text { conditional variance } \\
\text { equation }\end{array}$ & $\begin{array}{l}\text { Threshold } \\
\text { autoregressive } \\
\text { oconditional } \\
\text { heteroskedastistic } \\
\text { (TARCH) models } \\
\end{array}$ & $\begin{array}{l}\text { There is a steady } \\
\text { decline in the } \\
\text { ARCH term in all } \\
\text { markets with a less } \\
\text { consistent increase } \\
\text { in the GARCH } \\
\text { effect. The } \\
\text { asymmetric effect is } \\
\text { negative and } \\
\text { significant for the } \\
\text { entire period in all } \\
\text { markets, indicating } \\
\text { a strong market } \\
\text { response to } \\
\text { negative news. } \\
\text { There are regional } \\
\text { differences in } \\
\text { persistence of } \\
\text { volatility season } \\
\text { patterns across the } \\
\text { five markets. }\end{array}$ \\
\hline $\begin{array}{l}\text { Li and Flynn } \\
(2004)\end{array}$ & $\begin{array}{l}\text { Examine } \\
\text { patterns in } \\
\text { prices of the } \\
\text { deregulated } \\
\text { electricity } \\
\text { markets and } \\
\text { show whether } \\
\text { these } \\
\text { predictable } \\
\text { patterns can } \\
\text { shape future } \\
\text { actions of the } \\
\text { consumer }\end{array}$ & $\begin{array}{l}\text { Daily average } \\
\text { prices for } 13 \\
\text { deregulated } \\
\text { markets - } \\
\text { Canada, US (3 } \\
\text { markets) } \\
\text { Germany, } \\
\text { Britain, Spain, } \\
\text { Scandinavia, } \\
\text { Australia (4 } \\
\text { markets) and } \\
\text { New Zealand }\end{array}$ & $\begin{array}{l}\text { Average spot } \\
\text { price for each } \\
\text { period is } \\
\text { normalised } \\
\text { against the } \\
\text { average } \\
\text { weekday price } \\
\text { and similarly } \\
\text { for weekend } \\
\text { prices; ratio } \\
\text { maximum to } \\
\text { minimum } \\
\text { prices for } \\
\text { weekday and } \\
\text { weekend; and } \\
\text { ratio of } \\
\text { average } \\
\text { weekday to } \\
\text { average } \\
\text { weekend }\end{array}$ & NA & $\begin{array}{l}\text { Diurnal patterns; } \\
\text { filtering; and } \\
\text { correlation }\end{array}$ & $\begin{array}{l}\text { Britain and Spain } \\
\text { show electricity } \\
\text { price patterns that } \\
\text { are predictable and } \\
\text { consistent, } \\
\text { therefore } \\
\text { consumers can plan } \\
\text { their consumption } \\
\text { behaviours. In } \\
\text { South Australia the } \\
\text { price patterns are } \\
\text { irregular and } \\
\text { inconsistent, so } \\
\text { customers have to } \\
\text { manage their risks } \\
\text { through hedging } \\
\text { mechanisms. }\end{array}$ \\
\hline $\begin{array}{l}\text { de Jong } \\
\text { (2005) }\end{array}$ & $\begin{array}{l}\text { Capture the } \\
\text { spike in the } \\
\text { spot electricity } \\
\text { markets }\end{array}$ & $\begin{array}{l}\text { Hourly spot } \\
\text { prices for six } \\
\text { European and } \\
\text { two US } \\
\text { electricity } \\
\text { markets with } \\
\text { one market } \\
\text { starting from } \\
\text { January } 2002 \\
\text { and another } \\
\text { April } 2002 \text { and } \\
\text { the remaining } \\
\text { six starting from } \\
\text { January } 2001 \\
\text { with all markets } \\
\text { ending in March } \\
2004\end{array}$ & $\begin{array}{l}\text { Log spot } \\
\text { prices }\end{array}$ & $\begin{array}{l}\text { Deterministic and } \\
\text { stochastic } \\
\text { components }\end{array}$ & $\begin{array}{l}\text { The stochastic } \\
\text { components } \\
\text { including: Mean- } \\
\text { reverting; stochastic } \\
\text { Poisson jumps; } \\
\text { regime switching } \\
\text { with stochastic } \\
\text { Poisson jumps; } \\
\text { three regime- } \\
\text { switching and } \\
\text { stochastic Poisson } \\
\text { jumps; regime } \\
\text { switching with } \\
\text { independent spikes }\end{array}$ & $\begin{array}{l}\text { Regime switching } \\
\text { models out-perform } \\
\text { GARCH or Poisson } \\
\text { cjump models in } \\
\text { capturing the } \\
\text { dynamics of } \\
\text { electricity prices. }\end{array}$ \\
\hline
\end{tabular}




\begin{tabular}{|c|c|c|c|c|c|c|}
\hline Author(s) & $\begin{array}{l}\text { Study } \\
\text { objective(s) }\end{array}$ & Sample & $\begin{array}{l}\text { Dependent } \\
\text { Variable }\end{array}$ & $\begin{array}{l}\text { Independent } \\
\text { Variables }\end{array}$ & Technique(s) & Main Findings \\
\hline $\begin{array}{l}\text { Higgs and } \\
\text { Worthington } \\
(2005)\end{array}$ & $\begin{array}{l}\text { Profile intraday } \\
\text { price volatility } \\
\text { dynamics in } \\
\text { four Australian } \\
\text { electricity } \\
\text { markets }\end{array}$ & $\begin{array}{l}\text { yHalf hourly } \\
\text { electricity prices } \\
\text { and demand } \\
\text { volumes from } 1 \\
\text { January } 2002 \\
\text { to } 1 \text { June } 2003 \\
\text { for each of the } \\
\text { four spot } \\
\text { electricity } \\
\text { markets in } \\
\text { Australia: } \\
\text { namely: New } \\
\text { South Wales; } \\
\text { Queensland; } \\
\text { South Australia } \\
\text { and Victoria }\end{array}$ & $\begin{array}{l}\text { Half hourly } \\
\text { sspot electricit) } \\
\text { prices }\end{array}$ & $\begin{array}{l}\text { Lagged spot } \\
\text { y electricity prices in } \\
\text { the conditional } \\
\text { mean; and } \\
\text { contemporaneous } \\
\text { volume of demand; } \\
\text { time-of-day; day-of- } \\
\text { week; month-of- } \\
\text { year effects; } \\
\text { asymmetric volatility } \\
\text { response; } \\
\text { skewness; and fat- } \\
\text { tailed } \\
\text { characteristics of } \\
\text { spot electricity } \\
\text { prices in the } \\
\text { conditional variance } \\
\text { equations }\end{array}$ & $\begin{array}{l}\text { GARCH; } \\
\text { RiskMetrics; normal } \\
\text { Asymmetric Power } \\
\text { ARCH (APARCH); } \\
\text { Student APARCH } \\
\text { and skewed } \\
\text { Student APARCH }\end{array}$ & $\begin{array}{l}\text { The skewed } \\
\text { I Student APARCH } \\
\text { model, which takes } \\
\text { account of right } \\
\text { skewed and fat- } \\
\text { tailed } \\
\text { characteristics, } \\
\text { produces the best } \\
\text { results in all four } \\
\text { markets. The } \\
\text { results indicate } \\
\text { significant } \\
\text { innovation } \\
\text { spillovers (ARCH } \\
\text { effects) and } \\
\text { volatility spillovers } \\
\text { (GARCH effects) in } \\
\text { the conditional } \\
\text { standard deviation } \\
\text { equation, even with } \\
\text { market and } \\
\text { calendar effects } \\
\text { included. Intraday } \\
\text { prices also exhibit } \\
\text { significant } \\
\text { asymmetric } \\
\text { responses of } \\
\text { volatility to the flow } \\
\text { of information. }\end{array}$ \\
\hline $\begin{array}{l}\text { Worthington, } \\
\text { Kay-Spratly } \\
\text { and Higgs } \\
(2005)\end{array}$ & $\begin{array}{l}\text { Examine the } \\
\text { inter- } \\
\text { relationship of } \\
\text { spot electricity } \\
\text { prices and } \\
\text { price volatility } \\
\text { between five } \\
\text { regional } \\
\text { electricity } \\
\text { markets in } \\
\text { Australia }\end{array}$ & $\begin{array}{l}\text { Daily spot } \\
\text { prices spanning } \\
13 \text { December } \\
1998 \text { to } 30 \\
\text { June } 2001 \text { for } \\
\text { five regional } \\
\text { markets, } \\
\text { namely: New } \\
\text { South Wales; } \\
\text { Queensland; } \\
\text { South Australia; } \\
\text { Snowy } \\
\text { Mountain } \\
\text { Hydroelectric } \\
\text { Scheme and } \\
\text { Victoria }\end{array}$ & $\begin{array}{l}\text { Average daily } \\
\text { gspot prices }\end{array}$ & $\begin{array}{l}\text { Lagged prices of its } \\
\text { own and lagged } \\
\text { prices of the other } \\
\text { four electricity } \\
\text { markets }\end{array}$ & $\begin{array}{l}\text { Multivariate } \\
\text { generalised } \\
\text { autoregressive } \\
\text { conditional } \\
\text { heteroskedasticity } \\
\text { (MGARCH) model }\end{array}$ & $\begin{array}{l}\text { The results indicate } \\
\text { the presence of } \\
\text { positive own mean } \\
\text { spillovers in only a } \\
\text { small number of } \\
\text { markets and no } \\
\text { mean spillovers } \\
\text { between any of the } \\
\text { markets. This } \\
\text { appears to be } \\
\text { directly related to } \\
\text { the physical transfer } \\
\text { limitations of the } \\
\text { present system of } \\
\text { regional } \\
\text { interconnection. } \\
\text { The large number } \\
\text { of significant own- } \\
\text { volatility and cross- } \\
\text { volatility spillovers } \\
\text { in all five markets } \\
\text { indicates the } \\
\text { presence of strong } \\
\text { ARCH and GARCH } \\
\text { effects. This } \\
\text { indicates that } \\
\text { shocks in some } \\
\text { markets will affect } \\
\text { price volatility in } \\
\text { others. }\end{array}$ \\
\hline
\end{tabular}




\begin{tabular}{|c|c|c|c|c|c|c|}
\hline$\overline{\text { Author(s) }}$ & $\begin{array}{l}\text { Study } \\
\text { objective(s) }\end{array}$ & Sample & $\begin{array}{l}\text { Dependent } \\
\text { Variable }\end{array}$ & $\begin{array}{l}\text { Independent } \\
\text { Variables }\end{array}$ & Technique(s) & Main Findings \\
\hline $\begin{array}{l}\text { Chan and } \\
\text { Gray (2006) }\end{array}$ & $\begin{array}{l}\text { Univariate } \\
\text { modelling of } \\
\text { the } \\
\text { relationship of } \\
\text { five } \\
\text { international } \\
\text { spot electricity } \\
\text { markets: } \\
\text { Victoria } \\
\text { (Australia); } \\
\text { NordPool; } \\
\text { Alberta } \\
\text { (Canada); } \\
\text { Hayward (NZ) } \\
\text { and PJM (US) }\end{array}$ & $\begin{array}{l}\text { Daily In sample } \\
\text { data spot } \\
\text { electricity } \\
\text { prices: Victoria } \\
\text { from } 4 \text { January } \\
\text { 1999; } \\
\text { NordPool, } \\
\text { Alberts, } \\
\text { Hayward and } \\
\text { PJM from } 5 \\
\text { January } 1998 \\
\text { with all series } \\
\text { ending on } 31 \\
\text { December } 2002\end{array}$ & $\begin{array}{l}\text { Average daily } \\
\text { spot electricity } \\
\text { returns } \\
2\end{array}$ & $\begin{array}{l}\text { Lagged own return } \\
\text { and day-of-week } \\
\text { effects in the } \\
\text { conditional mean } \\
\text { equation and } \\
\text { variance (VaR) } \\
\text { equation. }\end{array}$ & $\begin{array}{l}\text { SThe VaR equation } \\
\text { with a non } \\
\text { parametric historica } \\
\text { simulation (HS) } \\
\text { approach and } \\
\text { various parametric } \\
\text { estimations such as } \\
\text { constant variance } \\
\text { (ConVar) and } \\
\text { EGACH with } \\
\text { extreme value } \\
\text { theory (EVT) }\end{array}$ & $\begin{array}{l}\text { The autoregressive } \\
\text { EGARCH-EVT } \\
\text { Imodel best } \\
\text { captures the time } \\
\text { series features of } \\
\text { both the mean and } \\
\text { volatility of returns } \\
\text { and explicitly } \\
\text { models the fat-tails } \\
\text { of the spot } \\
\text { electricity returns. } \\
\text { The autoregressive } \\
\text { EGARCH-EVT } \\
\text { model produces } \\
\text { more accurate out- } \\
\text { of-sample forecasts } \\
\text { and is useful in } \\
\text { forecasting VaR in } \\
\text { four international } \\
\text { spot electricity } \\
\text { markets. }\end{array}$ \\
\hline
\end{tabular}

\begin{tabular}{|c|c|c|c|c|c|c|}
\hline $\begin{array}{l}\text { Mount, Ning } \\
\text { and Cai } \\
\text { (2006) }\end{array}$ & $\begin{array}{l}\text { Capture the } \\
\text { spike in the } \\
\text { PJM (US) } \\
\text { power pool }\end{array}$ & $\begin{array}{l}\text { Daily spot } \\
\text { electricity price } \\
\text { from May } 1999 \\
\text { to May } 2000\end{array}$ & $\begin{array}{l}\text { Logarithm of } \\
\text { spot electricity } \\
\text { prices }\end{array}$ & $\begin{array}{l}\text { Deterministic and } \\
\text { / stochastic } \\
\text { components }\end{array}$ & $\begin{array}{l}\text { Stochastic two } \\
\text { regime-switching } \\
\text { model with time- } \\
\text { varying parameters } \\
\text { in the Markov } \\
\text { transition } \\
\text { probabilities }\end{array}$ & $\begin{array}{l}\text { The stochastic } \\
\text { regime-switching } \\
\text { model with two } \\
\text { regimes and two } \\
\text { transition } \\
\text { probabilities } \\
\text { including load } \\
\text { and/or the implicit } \\
\text { load margin } \\
\text { effectively predicts } \\
\text { the switching } \\
\text { probability from the } \\
\text { low and high of the } \\
\text { price spikes in the } \\
\text { PJM spot electricity } \\
\text { market. }\end{array}$ \\
\hline
\end{tabular}

\begin{tabular}{|c|c|c|c|c|c|c|}
\hline $\begin{array}{l}\text { Koopman, } \\
\text { Ooms and } \\
\text { Carnero } \\
(2007)\end{array}$ & $\begin{array}{l}\text { Model daily } \\
\text { spot electricity } \\
\text { prices in the } \\
\text { NordPool and } \\
\text { three } \\
\text { European } \\
\text { electricity } \\
\text { markets: EEX } \\
\text { in Germany; } \\
\text { Powernext in } \\
\text { France and } \\
\text { APX in } \\
\text { Netherlands }\end{array}$ & $\begin{array}{l}\text { Daily prices for } \\
\text { NordPool } \\
\text { staring on } 4 \\
\text { January 1993; } \\
\text { EEX } 1 \text { October } \\
2001 ; \\
\text { Powernext } 3 \\
\text { December } 2001 \\
\text { and APX } 1 \\
\text { January } 2001 \\
\text { with all series } \\
\text { ending on } 10 \\
\text { April 2005 }\end{array}$ & $\begin{array}{l}\text { Daily log spot } \\
\text { electricity } \\
\text { prices }\end{array}$ & $\begin{array}{l}\text { The conditional } \\
\text { mean equation } \\
\text { include lagged } \\
\text { dependent variables } \\
\text { to model short-run } \\
\text { dynamics and } \\
\text { seasonal Day-of } \\
\text { week effects and } \\
\text { explanatory variable } \\
\text { to capture the } \\
\text { demand and supply } \\
\text { effects }\end{array}$ & $\begin{array}{l}\text { Periodic seasonal } \\
\text { autoregressive } \\
\text { fractionally } \\
\text { sintegrated moving } \\
\text { average (ARFIMA) } \\
\text { GARCH models }\end{array}$ & $\begin{array}{l}\text { The daily log prices } \\
\text { are more persistent } \\
\text { in the NordPool as } \\
\text { compared to the } \\
\text { other three } \\
\text { European markets. } \\
\text { The periodic } \\
\text { seasonal ARFIMA } \\
\text { GARCH models } \\
\text { also capture the } \\
\text { long memory } \\
\text { characteristics of } \\
\text { the for European } \\
\text { spot electricity } \\
\text { markets. }\end{array}$ \\
\hline
\end{tabular}

Notes: ARCH - Autoregressive Conditional Heteroskedasticity, DF - Dickey-Fuller, ADF - Augmented Dickey-Fuller, GARCH - Generalised Autoregressive Conditional Heteroskedasticity, APARCH - Asymmetric Power Autoregressive Conditional Heteroskedasticity, MGARCH - Multivariate Generalised Autoregressive Conditional Heteroskedasticity, Autoregressive Fractionally Integrated Moving Average - ARFIMA, OLS - Ordinary Least Squares. 


\section{REFERENCES}

Bierbrauer, M., Truck, S., Weron, R. (2004). "Modelling electricity prices with regime switching models, Lecture Notes in Computer Science, Workshop on Computational Methods in Finance and Insurance", Springer, Berlin, 859-867

Booth, R. (2004). "Too much volatility is bad for you", WWW site: http://www.bardak.com.au. Accessed November 2005.

Boyer, M., Robert, J. (1997). "Competition and access in electricity markets: ECPR, Global price cap, and auctions", CIRANO, Montreal.

Bystrom, H.N.E. (2003). "The hedging performance of electricity futures on the Nordic power exchange", Applied Economics, 35(1), 1-11.

Chan, K.F., Gray, P. (2006). "Using extreme value theory to measure value-at-risk for daily electricity spot prices", International Journal of Forecasting, 22(2), 283-300.

Clewlow, L., Strickland, C. (2000). "Energy derivatives - pricing and risk management", Lacima Publications, London.

de Jong, C. (2006). "The nature of power spikes: A regime-switching approach", Cyriel De Jong (2006) "The Nature of Power Spikes: A Regime-Switch Approach", Studies in Nonlinear Dynamics and Econometrics, 10(3), Article 3.

de Jong, C., Huisman, R. (2002). "Option formulas for mean-reverting power prices with spikes”, Rotterdam School of Management, Erasmus University Rotterdam, Working Paper.

De Vany, A.S., Walls, W.D. (1999a). "Co-integration analysis of spot electricity prices: Insights on transmission efficiency in the western US", Energy Economics, 21(3), 435-448.

De Vany, A.S., Walls, W.D. (1999b). "Price dynamics in a network of decentralized power markets", Journal of Regulatory Economics, 15(2), 123-140.

Deng, S. (2000). "Stochastic models of energy commodity prices and their applications: Mean-reversion with jumps and spikes". University of California Energy Institute Working Paper No. 73, Los Angeles.

Escribano, A., Pena, J.I., Villaplana, P. (2002). "Modeling electricity prices: International evidence", Working Paper 02-27, Economics Series 08, Departmento de Economia, Universidad Carlos III de Madrid.

Goto, M., Karolyi, G.A. (2003) "Understanding electricity price volatility within and across Markets”, Working Paper.

Guthrie, G., Videbeck, S. (2002). "High frequency electricity spot price dynamics: An intraday markets approach", New Zealand Institute for the Study of Competition and Regulation.

Hadsell, L., Marathe, A., Shawky, H.A. (2004). "Estimating the volatility of wholesale electricity spot prices in the US”, Energy Journal, 25(4), 23-40. 
Helm, D., Powell, A. (1992). "Pool prices, contracts and regulation in the British electricity supply industry”, Fiscal Studies, 13(1), 89-105.

Higgs, H., Worthington, A.C. (2005). "Systematic features of high-frequency volatility in Australian electricity markets: Intraday patterns, information arrival and calendar effects", Energy Journal, 26(4), 1-19.

Huisman, R., Mahieu, R. (2003). "Regime jumps in electricity prices", Energy Economics, 25(5), 425-434.

Kaminski, V. (1999). "Managing energy price risk”, Risk Books, ed. by Kaminski, V., London.

Knittel, C.R., Roberts, M.R. (2001). “An empirical examination of deregulated electricity prices”, University of California Energy Institute, Working Paper.

Koopman, S.J., Ooms, M., Carnero, M.A. (2007). "Periodic seasonal reg-ARFIMAGARCH models for daily electricity spot prices", Journal of the American Statistical Association, 102(477), 16-27.

Li, Y., Flynn, P.C. (2004). "Deregulated power prices: Comparison of diurnal patterns", Energy Policy, 32(5), 657-672.

Lucia, J.J., Schwartz, E.S. (2002). "Electricity prices and power derivatives: Evidence for the Nordic power exchange”, Review of Derivatives Research, 5(1), 5-50.

Mount, T. (1999). "Market power and price volatility in restructured markets for electricity", Proceedings of the 32nd Hawaii International Conference on System Sciences.

Mount, T.D., Ning, Y., Cai, X., (2006). "Predicting price spikes in electricity markets using a regime-switching model with time-varying parameters", Energy Economics, 28(1), 62-80.

Pilipovic, D. (1998). "Energy risk: Valuing and managing energy derivatives", McGrawHill, New York.

Robinson, T. (2000). "Electricity pool series: A case study in non-linear time series modelling", Applied Economics, 32(5), 527-532.

Robinson, T., Baniak, A. (2002). "The volatility of prices in the English and Welsh electricity pool”, Applied Economics, 34(12), 1487-1495.

Robinson, T.A., Taylor, M.P. (1998). "Regulatory uncertainty and the volatility of regional electricity company share prices: The economic consequence of Professor Littlechild", Bulletin of Economic Research, 50(1), 37-44.

Solibakke, P. (2002). "Efficient estimated mean and volatility characteristics for the Nordic spot electricity power market", International Journal of Business, 7(2), 17-35.

Walls, W.D. (1999). "Volatility, volume and maturity in electricity futures", Applied Financial Economics, 9(3), 283-287. 
Wolak, F.A. (2000). "Market design and price behaviour in restructured electricity markets: An international comparison", NBER-East Asia Seminar on Economics, vol. 8. Chicago and London: University of Chicago Press.

Worthington, A.C., Kay-Spratley, A., Higgs, H. (2005). "Transmission of prices and price volatility in Australian electricity spot markets: A multivariate GARCH analysis", Energy Economics, 27(2), 337-350. 